\title{
Extramural Exposure and Language Attainment: The Examination of Input-Related Variables in CLIL Programmes
}

\author{
NinA Karen LANCASTER \\ City Heights E-ACT Academy
}

Received: 28 May 2017 / Accepted: 3 October 2017

ISSN: $1697-7467$

\begin{abstract}
This article documents the findings of a quantitative study to gauge the impact of CLIL and extramural exposure on foreign language attainment. The relationship between CLIL and input-related variables is examined from a double-fold perspective. First, it is determined if CLIL scenarios favour more extramural exposure to English (in the form of books and magazines, TV series and movies, the Internet and videogames, songs and private lessons). Then, we reveal if language outcomes are better by means of CLIL or Formal Instruction (FI) and how this varies according to type of school. Finally, we explore whether the language proficiency differential between the CLIL and the EFL groups can be ascribed to this extramural exposure or whether other variables (such as motivation, verbal intelligence, socioeconomic status, or the CLIL programme itself) account for the greatest proportion of variance. Ten public bilingual and charter schools (in Primary and Compulsory Secondary Education) in the autonomous community of Extremadura have taken part in the study, with a total of 156 CLIL learners and $162 \mathrm{EFL}$ students.
\end{abstract}

Keywords: CLIL, FI, extramural exposure, L2 competence

La exposición extramural y el dominio del inglés: Los efectos de las variables relacionadas con el input en los programas AICLE

RESUMEN: Este artículo presenta los resultados de un estudio cuantitativo para determinar los efectos del AICLE y de la exposición extramural en el nivel de la lengua extranjera. Se examina la relación entre el AICLE y las variables relacionadas con el input desde una perspectiva bidimensional. En primer lugar, se identifica si la participación en programas AICLE fomenta una mayor exposición al inglés (a través de los libros y las revistas, las series de televisión y las películas, Internet, videojuegos y clases particulares). Posteriormente, se evidencia si los resultados son mejores mediante el AICLE o la docencia formal y como varían según el tipo de colegio. Para finalizar, se estudia si se puede atribuir el diferencial del dominio de la lengua extranjera entre los grupos AICLE y los de enseñanza tradicional a esta exposición extramural o si otras variables (tales como la motivación, la inteligencia verbal, el nivel socioeconómico o el programa AICLE en sí) explican la mayor parte de la varianza. El estudio se ha realizado en la comunidad autónoma de Extremadura con la participación de diez colegios públicos bilingües y concertados (en Educación Primaria y Secundaria Obligatoria), con 156 alumnos bilingües y 162 alumnos de la enseñanza tradicional.

Palabras clave: AICLE, enseñanza tradicional, exposición extramural, nivel de inglés 


\section{INTRODUCTION}

European governments introduced Content and Language Integrated Learning (CLIL) programmes in an endeavour to promote foreign language learning in order to meet the demands of our increasingly globalised society. Over the past two decades we have witnessed a rapid spread of this methodology throughout Europe in such a manner that it has been claimed "multilingualism is seizing schools and the CLIL scheme has grown stronger as a solution" (Lorenzo, Casal \& Moore, 2009: 29).

This in-vogue phenomenon entails increased exposure, allowing subconscious meaningful acquisition of language as opposed to explicit techniques of formal instruction (FI). Paran (2013: 329) feels "it is important to understand the complexities of achieving the integration that is part of the acronym CLIL". Focus is taken away from the content knowledge and veered towards meaning-making in the context of systematic functional linguistics, which is perceived as generating fruitful learning. It has been reported that students reinforce links between the "conceptual continuum" and the "communication continuum" and this is how meaning is made (Meyer, Coyle, Halbach, Schuck \& Ting, 2015: 50). Parallels have been mapped out between CLIL and extramural exposure to English in this sense as "CLIL and extramural English in fact have many aspects in common as regards how English is learned" (Sylvén \& Sundqvist, 2015: 48). A clearer picture is painted when we comprehend "the primary underlying argument for the use of CLIL is that the greater the exposure to a language, the easier it is learned" (Sylvén \& Sundqvist, 2015: 49). The two approaches display common learning principles such as active, critical learning, identity and practice principles (Sylvén \& Sundqvist, 2012c); however, these authors have only just scratched the surface regarding the uncovering of this close relationship, making a strong case for further exploration.

From an inverse perspective, CLIL can be contrasted to formal instruction in terms of the meaning versus form dispute, bringing into question the debate as to whether it would be CLIL as meaningful learning or FI with a focus on form which would contribute most to increased foreign language proficiency. Extramural exposure can exist as formal instruction in Spain in the form of extra classes of English provided by private academies. The existence of these establishments, dedicated to the improvement of Spaniards' foreign language skills, equip us with an additional scope of research to probe.

The vivacious research scene in which scholars strive to enlighten education enthusiasts on the effects of CLIL alone have contributed both positive and, more recently, negative accounts. Nevertheless, as Pérez Cañado (2011: 389) underscores "in order to bolster the process of implementation of CLIL programmes and to guarantee their success, we need to depart from solid evidence in which we are still sorely lacking [...]. Paran (2013: 322-323) denotes that "[...] research has sometimes struggled to show the benefit of CLIL, even for language outcomes". Disregarding this deficit of substantial research, CLIL has undeniably been on academics' radars, especially of late. Sylvén and Sundqvist (2015) testify that "whereas CLIL has recently attracted a great deal of scholarly attention, learners' engagement in language-related extramural activities remain rather unexplored" (p. 59-60), acquainting us with the extent to which extramural exposure needs to be prioritized for investigation, particularly in relation to CLIL.

It is evident we are in pursuit of stalwart empirical evidence and that is exactly what this article strives to provide by reporting on a study which examines and contrasts extramural 
exposure in CLIL and non-CLIL scenarios and analyses language attainment according to language methodology (CLIL of FI) in a monolingual context. This investigation, framed within two governmentally-funded research projects, rectifies shortcomings present in prior studies as regards the initial homogeneity of the CLIL treatment and non-CLIL comparison groups, the comparability of instruments and the longitudinal nature of the studies in our context to date (Lorenzo, Casal \& Moore, 2009; Madrid \& Hughes, 2011). Additionally, the sample involves two different educational levels (Primary and Secondary), factors in intervening variables vis-à-vis extramural exposure and type of school, and performs multivariate analyses in order to decipher to which variables the differences in language competence can be ascribed.

A preliminary section is dedicated to underpinning the topic of extramural exposure and describing its connection to CLIL through a synopsis of existing research in Europe, followed by a delineation of the research design employed in the study, prior to the prime focus, which will be awarded to the dissemination of results and a discussion of the research. In a final section, chief conclusions will be highlighted, inclusive of noteworthy pedagogical implications elicited from the key findings.

\section{TheOretical FRAMEWORK}

Extramural exposure has been referred to as functional practice (Bialystok, 1981), as opposed to formal instruction within a classroom. With reference to language learning, this author highlights that "the most functional situation would likely occur outside the classroom, in a natural setting, where conveying the message is the only essential goal of the language occasion" (Bialystok, 1981). In recent times, taking into account the ever increasing use of digital media, the learning of a foreign language through digital environments is labelled as language-as-social-practice (Barton \& Potts, 2013). In order to fine-tune extramural exposure, in line with the current study, we can refer to extramural exposure as extramural English (EE) to pertain to out-of-class learning of English. Sundqvist (2009) first introduced this distinct term in order to evade the negative connotations and implications of passiveness that the word exposure gave rise to.

Extramural English encompasses "input, output, and/or interaction in English; that is, the essential components needed for second language (L2) learning are in place" (Sundqvist \& Sylvén, 2016: loc 440). Conversations with native speakers when abroad and using interactive, multimedia resources in the form of Massively Multiplayer Online Role-Playing Games (MMORPGs) can be adopted as means to increase English exposure outside of the classroom, in addition to activities such as listening to the radio, watching television and reading novels and newspapers, the latter grouping requiring less active engagement. Preferences of students vary depending on individual learning styles and existing studies yield informative results, which will now be expounded upon.

It is necessary to document that an abundance of research has been executed in Sweden as a result of the national curriculum for English in this particular country taking advantage of the variety of extramural English within its society to implement curricular content which addresses students' interests and needs. Outcomes reveal extramural English is conducive to the improvement of language skills (Sundqvist, 2009; Sylvén, 2004b/2010; Sylvén \& Sundqvist, 2015). 
A one-year study with a mixed methods research design carried out by Sundqvist (2009) investigated extramural exposure of Swedish learners of English in grade 9 by means of language diaries, a questionnaire, five interactional speaking tests and two written vocabulary tests. The results indicated a positive correlation between extramural English and both oral proficiency and vocabulary performance. The extramural activities that demanded learners to be more productive had a greater influence on vocabulary and oral proficiency. It emerged that boys tended to resort to the more productive activities in contrast to passive options resulting in their achieving better results than the female cohort.

Sylvén $(2004 b, 2010)$ also administered vocabulary tests to Swedish students of Secondary Education and it transpired that the students who were found to receive the largest amounts of English input produced the best test results. An interesting finding in this study established that the students who excelled in acquiring vocabulary had a propensity to read texts independently, suggesting that the most autonomous learners are the students who benefit to the greatest extent. Motivation and learner autonomy are crucial issues embodied in extramural English and will be subsequently elaborated on.

A significant contribution extolling on the virtues of extramural English brings forth encouraging findings and outlines precise implications to make best use of extramural English. Sylvén and Sunqvist (2015) conducted a study of a larger scope over one semester employing a language diary, a questionnaire, a vocabulary test comprising recognition and production, and a national test of English focusing on five areas of competence (interactive speaking, listening comprehension, reading comprehension, writing skills and self-assessment). A salient conclusion indicated that young Swedish language learners dedicate a substantial amount of their time to extramural English activities, specifically on the Internet and gaming. One of the predominant takeaways from the study is that young learners benefit from extramural English to improve their language skills and the relationship between extramural English and proficiency can be described as bidirectional and mutually reinforcing. It is important to remember that extramural English cannot be used as a substitute for formal instruction but acts as a complement, an accompaniment that teachers need to be aware of to fully take advantage of such beneficial circumstances.

To resume focus on learner autonomy, we are able to attest its relevance from an extramural exposure standpoint. In fact, for out-of-class learning to take place, motivation is essential in the same way extramural English is intimately linked to learner autonomy. Taking part in extramural English activities chosen by themselves provides students with a sense of enjoyment and this, in turn, spurs on the learning process, making a strong case for the role of learner autonomy in successful L2 learning (Arnold, 2009; Chik \& Breidback, 2011; Lamb, 2004, Pearson, 2004; Purushotma, 2005, as cited in Sundqvist \& Sylvén, 2016).

We will now proceed to address each type of extramural activity independently due to the fact that learners progress to varying degrees depending on which media element they decide to engage in (Berns, de Bot \& Hasebrink, 2007). Watching television and films was the aspect of extramural English to be first researched. Subtitled TV programmes and how they affect foreign language acquisition was studied in depth before the start of the millennium. The best scenario to produce the most gains pertaining to increasing performance entailed watching the material in the L2 with the aid of subtitles in the L1 (d'Ydewalle \& Van de Poel, 1999). Caimi (2006) illustrates that language comprehension is aided through the educator's intentional decision to combine phonological expression with written form. 
It is the synthesis of sounds, images and text that allows any aspect of real life to be introduced into language learning (Talaván Zanón, 2013). TV programmes to promote L2 learning positively impinge on receptive and productive oral skills and cultural issues (Caimi, 2006; Rogers \& Webb, 2011). As a result of these positive effects, students are more inclined to continue watching subtitled videos as a means to improve their foreign language learning (Caimi, 2006)

Reading and writing skills have starkly received attention in connection to extramural English, although Sylvén (2006) underscores that "exposure to English texts has a positive effect on lexical acquisition" (p. 47-48) and Arnold (2009), as cited in Sundqvist and Sylvén (2016), discloses that language competence is boosted through extensive reading of challenging texts. It has been claimed that, in spite of study abroad being superior to all other contexts, it prevails as a difficult aspect to measure with regard to its effects on L2 proficiency and also deserves separate attention due to its connection and fundamental comparison with CLIL and formal instruction.

Our overview of extramural English now brings us to shed light on the area which is proving to be most influential at the present time: digital gaming. Sundqvist and Sylvén (2016: loc 2818) articulate that "research more or less unanimously acknowledges the potential for L2 purposes held by various digital sources" and present digital gaming as a "prominent role for L2 learning compared to other EE" (loc 2999).

Gee (2007) created 36 learning principles that videogames teach students about learning and literacy, 20 of which can be linked to L2 learning (Sundqvist \& Sylvén, 2016). These principles range from aspects such as input to how knowledge can be transferred from one context to another. It is evident that gaming seems to be a lynchpin to motivate students to learn English, especially disinterested boys who have been known to lag behind in language learning. In light of the results by Sylvén and Sundqvist (2015), boys are more prone to play MMORPGs, whereas girls prefer single player, offline games. This results in boys superseding their female counterparts in L2 vocabulary acquisition, making a strong case for videogames as effective instruments in the development of language skills.

In order to report on the similarities between extramural English and CLIL and underscore their corresponding qualities as language learning methods, Sylvén and Sundqvist (2012c: 127) compare CLIL with playing the MMORPG World of Warcraft (WoW), drawing upon the language principles of immersion, authenticity and motivation. They evince that "what CLIL claims to do intramurally, that is, in the classroom, WoW does extramurally" in terms of promoting the use of the L2 and fostering interaction and communication. The researchers make a plea for further investigation into the principles employed in CLIL and non-CLIL classes to provide an insight into which approach is most efficient in bridging the gap between learning of English in school and out of school.

Sylvén and Sundqvist (2015: 59) corroborate the aforementioned declaration concluding that extramural English is beneficial to L2 learning and it is indisputable that "simultaneous learning of content and language may very well take place also outside school", which allows us to perceive extramural English as out-of-school CLIL. It is also brought to our attention that teachers must endorse extramural English and familiarise themselves with the different types available in the interest of assisting in learner progress.

To create a picture of how extramural exposure is used in CLIL classrooms, Sylvén (2006) designed a study to either prove or refute the hypothesis that CLIL teaching was 
inclined to take advantage of extracurricular exposure in the actual classroom. In the pilot study, the CLIL group demonstrated higher involvement in exposure to English in their free time and proved to make more use of extramural activities in class. On the other hand, the main study failed to demonstrate coinciding findings. CLIL students were, again, found to be more exposed to English outside of school in comparison to the non-CLIL branch, but the former were not subject to diverse materials in class, providing inconclusive results.

Olssen and Sylvén (2015) found that extramural English holds as much influence as CLIL with regard to aptitude in vocabulary and ascertain CLIL students devote considerably more time to English learning in their spare time when analysed against their mainstream peers. The conclusion emerged that male CLIL students include more academic vocabulary in their essays. Nevertheless, this particular group did not exhibit progress over time, leading the authors to call for more studies to be carried out to map out the impact of extramural English on fluency and grammar in writing skills.

Turning to a closer inspection on the relationship between extramural exposure and CLIL, we can allude to Sylvén's $(2004,2010)$ investigation into the effects of CLIL on incidental acquisition of English vocabulary. The results obtained focus on the positive effects of extramural English and depict that, regardless of the students being assigned to the CLIL or non-CLIL group, the students with the largest amounts of extramural English outperformed those students with less access. It can therefore be claimed that extramural English has a greater effect on incidental acquisition of vocabulary than CLIL.

Pérez-Vidal (2010: 9) compares the specific extramural exposure of study abroad (SA) with CLIL and FI. This scholar emphasizes that "[...] evidence has been accumulating in the past year that CLIL learners achieve higher levels of competence than their FI peers". Due to the fact that CLIL is communicative, target language instruction is constantly used and focus is on meaning rather than on form, it is placed closer on the continuum than FI in terms of communication. Previous research is presented to report on instances where SA has been undoubtedly more beneficial to students than FI with reference to oral, written and pragmatic competence (Dufon \& Churchill, 2006; Freed, 1995; Saaski, 2004, as cited in Pérez-Vidal, 2010) and when at home immersion programmes similar to CLIL are scrutinized, they have been known to be as influential as SA (Segalowitz \& Freed, 2004, as cited in Pérez-Vidal, 2010) or possibly even more advantageous (Freed, Segalowitz \& Dewey, 2004, as cited in Pérez-Vidal, 2010). Results from a similar study probing the same three contexts by Dewey (2008) tally with what has previously been articulated: SA and immersion students produce overall gains in vocabulary and immersion students supersede SA participants when oral fluency is examined.

To accomplish optimum outcomes, Pérez-Vidal (2010: 10) calls attention to a combination of contexts and declares "A SA, immersion context, following a healthy dose of classroom practice and attention to form which would place students at an upper intermediate level of proficiency can give better results than FI on its own". Despite CLIL programmes yielding benefits in terms of fluency, in order to guarantee gains in accuracy and sociolinguistic competence, a CLIL programme alone must ensure there is also a focus on form in class as a means to compensate the lack of FI.

This summary of previous research into extramural exposure and the parallels it possesses with CLIL has provided us with a clear idea of the current situation and it is fair to say that studies into both areas of investigation are still limited in number. As Sundqvist 
and Sylvén (2016: loc 576) acknowledge, "[...] this particular field is still under-researched within the broad field of SLA". In turn, in relation to CLIL, it has been propounded that "further research on the effect of different CLIL practices is needed to shed some more light on the interrelations between CLIL, extramural English and academic language" (Olsson \& Sylvén, 2015: 96).

In this vein, firstly, further studies need to be generated to further establish whether CLIL students are more predisposed to extramural exposure out of a classroom environment. Secondly, existing research has focused on extramural exposure in the form of SA compared to CLIL and FI (Dewey, 2008; Pérez-Vidal, 2010); however, within Spain the specific type of extramural English in need of exploration can be illustrated by private academies of English ${ }^{1}$. These after-school centres form a large part of a Spanish students' lives as they strive to become proficient in the English language, be it due to pleasure or outside pressures such as being able to compete for future employment opportunities. We can consider this extramural English as an instance of extra formal EFL instruction.

Subsequent aspects necessary to correct involve guaranteeing the homogeneity of the CLIL and non-CLIL samples within studies and the presence of intervening variables such as type of school, Socioeconomic Status (SES), verbal intelligence and motivation. Factoring in and controlling for these variables allow us to go one step further and perform multivariate analyses warranting the isolation of the variables with the aim of discovering which variables are actually responsible for the differences obtained.

In an endeavour to overcome the aforesaid lacunae, with the present study we seek to contribute solid empirical evidence from the perspectives outlined, as it has to be reiterated that "it is essential to look more closely at what makes extramural English and CLIL effective for language learning and at how one correlates with the other" (Sylvén \& Sundqvist, 2015: 60). In the following section of the article the description of the study will be delineated in detail.

\section{The STUdy}

This study forms part of an extensive research project with the objective of performing a large-scale evaluation of CLIL programmes in three distinct autonomous communities of Spain (Andalusia, Extremadura, and the Canary Islands), renowned for their lack of foreign language tradition and bilingual education. From a quantitative perspective, the effects of CLIL have been studied on language competence (grammar, vocabulary and the four skills), Spanish language competence and content knowledge of Natural Science subjects taught with the foreign language as a vehicle of instruction for Primary students ( $6^{\text {th }}$ grade) and Secondary Education students $\left(4^{\text {th }}\right.$ grade). Whether the effects of CLIL still pervade one year after the CLIL programme is discontinued is also established by means of a delayed post-test in the first year of Baccalaureate. The quantitative part of the study is then complemented from a qualitative point of view via a SWOT analysis carried out with all the chief stakeholders

${ }^{1}$ Private academies of English in Spain are private institutions which provide out of school English teaching to students of all ages. Often, they offer students the opportunity to take part in examinations in order to achieve CEFR level accreditations. 
(students, teachers, parents) on the satisfaction that is generated by specific aspects of the CLIL programmes by use of questionnaires, semi-structured interviews, focus groups, and direct behaviour observation. The study in question is encased in the quantitative side of the investigation and is an example of applied, primary, quasi-experimental research. It analyses extramural exposure of English and examines its respective relationship with CLIL, taking into account the following research questions.

\subsection{Research questions}

RQ1: Do CLIL scenarios favour more extramural exposure to English (in the form of books, and magazines, TV series and movies, the Internet and social networks, videogames and songs) and how does this vary according to type of school?

RQ2: Are language outcomes (use of English, vocabulary, listening, reading and speaking) better by means of extra formal instruction or through meaningful, subconscious acquisition and how does this vary according to type of school?

RQ3: Is the language attainment differential between the CLIL and EFL groups ascribed to extramural exposure or do other variables (such as socioeconomic status, verbal intelligence, motivation, or the CLIL programme itself) account for the greatest proportion of the variance?

\subsection{Research sample}

The sample of the study comprises 318 students from ten randomly selected public and charter schools in rural and urban areas of the monolingual autonomous community of Extremadura $^{2}$. There are 162 students who are completing the last year of Primary school $\left(6^{\text {th }}\right.$ grade) and 156 students finishing their final year in Secondary Education (4 $4^{\text {th }}$ grade). A greater number of students study at public schools (79\%), where CLIL streams and monolingual EFL mainstream peers exist side-by-side, whereas a smaller percentage (21\%) attend charter schools in which there are only EFL students. A higher percentage of students (64\%) study in schools in rural areas, whereas the remaining students $(36 \%)$ go to schools in urban regions. The total number of CLIL students was 156, whereas 162 students were in traditional EFL classes. A slighter higher percentage of males took part in the study $(55 \%)$ compared to females $(45 \%)$.

With reference to the experimental group (CLIL) and the control group (non-CLIL), it is essential to stress that initial homogeneity of both groups was guaranteed from the outset of the study. As Bruton (2011: 5) predicates, "unfortunately, there is dearth of research into comparisons between CLIL and comparable non-CLIL groups [...]", bringing to our attention that it is assumed the most linguistically competent, intelligent and motivated students populate the CLIL groups. With this in mind, in order to secure truly comparable groups, students within schools were matched in terms of verbal intelligence, motivation and En-

${ }^{2}$ In the Autonomous Community of Extremadura in Spain, bilingual sections exist at all levels of education. They are implemented gradually starting from the first year of every educational stage. A minimum of $20 \%$ of the curriculum must be taught in the foreign language up to a maximum of $50 \%$. All teachers participating in the bilingual programme must have a CEFR B2 accreditation. 
glish proficiency through the administration of tests to measure the first two variables and by collecting English grades of the students to affirm the third. After eliminating students who were classified as outliers (those with the highest or lowest scores), we were able to guarantee thoroughly homogenous samples incorporating students with a comparable level of intelligence, motivation and English level. It is necessary to highlight that double the amount of schools originally participated; however, the number was reduced posterior to the guaranteeing of homogeneity.

The tests measuring extramural exposure, verbal intelligence and motivation were carried out at the outset of the academic year and 30 minutes were required to complete each test. Once homogeneity was guaranteed, it was possible to administer the English tests to the homogenous groups. Both the written test (use of English, vocabulary, listening and reading) and the speaking test had a duration of one hour. The students were organised into pairs for the speaking part and the 10-minute test was recorded for further consultation. Two researchers were also present, an interviewer and an observer to take any necessary notes.

\subsection{Research variables}

Three types of variables have been taken into consideration: dependent, independent, and moderating ones.

- The dependent variable corresponds to the students' English language (L2) competence in terms of use of English, vocabulary, listening, reading and speaking skills.

- With regard to the independent variable, the CLIL programme is considered, which is implemented in the public school.

- Within moderating variables, the following have been taken into account:

- Extramural exposure

- Type of school (public-charter).

\subsection{Research instruments}

For the purpose of information-gathering, two different tests and one questionnaire (to measure verbal intelligence, motivation and extramural exposure, respectively) were employed in the initial stages of the study, along with an additional questionnaire to compile personal data and specify information on the parents' age and educational level in order to calculate socioeconomic status (SES). Both the tests for verbal intelligence and motivation and also the questionnaire for extramural exposure have been previously validated in either the field of psychology or language teaching research. The six tests used to determine students' English language competence were originally designed and validated and consisted in two different batteries of tests (use of English, vocabulary, reading, listening and speaking sections) corresponding to the two different levels of education being examined ( $6^{\text {th }}$ grade of Primary Education and $4^{\text {th }}$ grade of Compulsory Secondary Education).

- The verbal intelligence test included two versions to cater for both levels of education $\left(6^{\text {th }}\right.$ grade of Primary Education and $4^{\text {th }}$ grade of Compulsory Secondary Education). Taken from the EFAI (Evaluación Factorial de las Aptitudes Intelectuales) 
battery (Santamaría, Arribas, Pereña \& Seisdedos, 2016), students had to answer as many items as possible in five minutes (total of 26 items for Primary and 23 for Secondary), choosing from four multiple choice options, to test their knowledge on analogies, antonyms and odd-one-out.

- Pelechano's (1994) MA test was administered to measure motivation. Involving 35 different items, we can identify four contrasting motivational factors of achievement and anxiety: (i) vain desire to work and self-esteem (composing 10 elements); (ii) anxiety in the face of exams (with a negative-inhibitory content and comprising 9 aspects); (iii) lack of interest in studying (containing 9 elements); (iv) realistic personal self-demand (made up of 7 elements).

- The questionnaire to shed light on extramural exposure was based on a language diary created by Sundqvist and Sylvén (2014) and involved the students reflecting on their exposure to English outside of school to give examples and note down the number of hours dedicated to specific activities per week.

- The instruments to assess English language competence tests subsumed the six aspects above and the contents were created based on the Common European Framework of Reference (CEFR), the national Decrees, and the regional Orders on which the official curriculum for the different educational stages is established, presenting contents, descriptors, and evaluation strategies with a focus on grammatical, lexical, and skills-based features. (cf. Madrid, Bueno, \& Raéz, in press, to consult internal reliability and validity results). A detailed marking scheme was also fabricated to assess speaking competence composed of five distinct criteria: grammatical accuracy, lexical range, fluency and interaction, pronunciation and task fulfilment (cf. Pérez Cañado \& Lancaster, 2017). Subsequent to the design of the tests, a double pilot procedure was adopted with the first versions being scrutinized by a team of five external experts, who critically assessed their length, difficulty, variety of testing facets, types of inputs, clarity of rubrics, and layout. After feedback was given and any modifications were adjusted, they were applied to a representative sample of students of the same levels and of similar characteristics as our target participants to establish the internal consistency and reliability with the calculation of Chronbach alpha and the Kuder-Richardson reliability coefficients, index of difficulty and discrimination index of the items of the instruments. At this elementary stage, we also made sure the instruments met the main testing requirements recommended in the specialized literature (content, construct, face and ecological validity, reliability, and practicality).

\subsection{Research data analysis}

A statistical analysis of the data has been performed with the aid of the SPSS programme, in its 21.0 version. The statistically significant differences have been calculated between the experimental (CLIL) and the control (non-CLIL) groups through a one-way repeated measures analysis of variance (ANOVA) and paired samples $t$ tests, thereby guaranteeing the homogeneity and comparability of the sample for verbal intelligence, motivation and English level. ANOVA and paired sample $t$ tests have also been employed to detect any statistically significant differences between groups in terms of the moderating variables 
considered - extramural exposure and type of school - and Rosenthals's R and Cohen's d were employed to calculate effect sizes using Gpower 3.1 pertaining to research questions (RQs) one and two respectively. As regards RQ3, successive discriminant analyses have been performed in order for us to determine which variable(s) are truly responsible for any differences between the experimental and control groups

\section{REsults AND Discussion}

\subsection{Extramural exposure to English in CLIL and non-CLIL scenarios}

On inspection of the data, taking into consideration all levels of education as a whole (Primary and Secondary) and with no specification of type of school (public or charter), we are able to locate statistically significant differences between the CLIL and the non-CLIL students in favour of the former, which verifies that students in the CLIL group seek out more extramural exposure to English outside of school in comparison to their EFL counterparts (cf. Table 1). This is fully congruent with the trend manifested in relevant research conducted by Sylvén (2006) and Olsson and Sylvén (2015).

Table 1. Number of hours of extramural English per week

\begin{tabular}{|l|l|r|r|r|r|}
\hline & \multicolumn{1}{|c|}{ Group } & Mean & $\begin{array}{c}\text { Standard } \\
\text { deviation }\end{array}$ & Rosenthal's r & p value \\
\hline Hours/week of & Non-CLIL & 14.07 & 26.57 & -0.170 & 0.002 \\
English & CLIL & 16.27 & 21.53 & & \\
\hline
\end{tabular}

Taking a closer look at the results and identifying the outcomes bearing in mind the stage of education, although there are no statistically significant differences detected between the CLIL and non-CLIL students in Primary Education, it is clear Secondary Education CLIL students tend to be more exposed to English outside of school compared to EFL students, as the hours they dedicate to out of school English are significantly higher (cf. Table 2).

Table 2. Number of hours of extramural English per week according to educational level

\begin{tabular}{|c|c|c|c|c|c|c|}
\hline $\begin{array}{c}\text { Educational } \\
\text { level }\end{array}$ & & Group & Mean & $\begin{array}{l}\text { Standard } \\
\text { deviation }\end{array}$ & $\begin{array}{c}\text { Rosenthal's } \\
\mathbf{r}\end{array}$ & p value \\
\hline \multirow[t]{2}{*}{$\begin{array}{l}\text { Primary } \\
\text { Education }\end{array}$} & $\begin{array}{l}\text { Hours/week of } \\
\text { English }\end{array}$ & Non-CLIL & 10.30 & 22.67 & -0.129 & 0.102 \\
\hline & & CLIL & 11.03 & 14.59 & & \\
\hline \multirow[t]{2}{*}{$\begin{array}{l}\text { Secondary } \\
\text { Education }\end{array}$} & $\begin{array}{l}\text { Hours/week of } \\
\text { English }\end{array}$ & Non-CLIL & 17.75 & 29.57 & -0.220 & 0.006 \\
\hline & & CLIL & 22.08 & 26.14 & & \\
\hline
\end{tabular}


Within the public school, encompassing CLIL and non-CLIL streams, a similar pattern emerges with reference to Secondary Education students. Students in the $4^{\text {th }}$ grade of this education level in the CLIL branch again spend more time learning English out of school when they are analysed against their mainstream peers. However, no statistically differences were found for both levels of education together or for Primary alone, emphasizing the fact that students of a certain age (15-16) tend to devote out-of-school hours to English learning (cf. Table 3).

Table 3. Number of hours of extramural exposure per week in the public school according to educational level

\begin{tabular}{|c|c|c|c|c|c|c|}
\hline $\begin{array}{c}\text { Educational } \\
\text { level }\end{array}$ & & Group & Mean & $\begin{array}{l}\text { Standard } \\
\text { deviation }\end{array}$ & $\begin{array}{c}\text { Rosenthal's } \\
\mathbf{r}\end{array}$ & $p$ value \\
\hline $\begin{array}{l}\text { Primary } \\
\text { Education }\end{array}$ & $\begin{array}{l}\text { Hours/week of } \\
\text { English }\end{array}$ & $\begin{array}{l}\text { Non-CLIL } \\
\text { CLIL }\end{array}$ & $\begin{array}{l}16.16 \\
11.03\end{array}$ & $\begin{array}{l}34.63 \\
14.59\end{array}$ & -0.072 & 0.441 \\
\hline $\begin{array}{l}\text { Secondary } \\
\text { Education }\end{array}$ & $\begin{array}{l}\text { Hours/week of } \\
\text { English }\end{array}$ & $\begin{array}{l}\text { Non-CLIL } \\
\text { CLIL }\end{array}$ & $\begin{array}{l}18.97 \\
22.08\end{array}$ & $\begin{array}{l}32.79 \\
26.14\end{array}$ & -0.224 & 0.008 \\
\hline
\end{tabular}

With a view to identifying the variation in exposure to English outside of school between two opposing groups in different types of schools (a CLIL group in a public school and the non-CLIL students in the charter school) we encounter contradictory situations for the two groups. Statistically significant differences are present across the board (for Primary, Secondary and both stages together), with CLIL students in all situations spending more hours on English out of school (cf. Tables 4 and 5). These results allow us to ascertain that those belonging to the CLIL group in the public school, regardless of which stage of education they form part of, are inclined to study extra English out of school hours than the non-CLIL students attending the charter school.

Table 4. Number of hours of extramural exposure per week in the public school and the charter school

\begin{tabular}{|lc|r|r|r|c|}
\hline & Group & Mean & $\begin{array}{r}\text { Standard } \\
\text { deviation }\end{array}$ & Rosenthal's r & p value \\
\hline $\begin{array}{l}\text { Hours/week of } \\
\text { English }\end{array}$ & Non-CLIL & 5.48 & 8.06 & -0.436 & $<0.001$ \\
& CLIL & 16.27 & 21.53 & & \\
\hline
\end{tabular}


Table 5. Number of hours of extramural exposure per week in the public school and the charter school according to educational level

\begin{tabular}{|lll|r|r|r|c|}
\hline $\begin{array}{l}\text { Educational } \\
\text { level }\end{array}$ & Group & Mean & $\begin{array}{r}\text { Standard } \\
\text { deviation }\end{array}$ & Rosenthal's r & p value \\
\hline $\begin{array}{l}\text { Primary } \\
\text { Education }\end{array}$ & $\begin{array}{l}\text { Hours/week } \\
\text { of English }\end{array}$ & Non-CLIL & 5.90 & 5.84 & -0.207 & 0.017 \\
& CLIL & 11.03 & 14.59 & & \\
$\begin{array}{l}\text { Secondary } \\
\text { Education }\end{array}$ & $\begin{array}{l}\text { Hours/week } \\
\text { of English }\end{array}$ & Non-CLIL & 5.03 & 9.97 & -0.588 & $<0.001$ \\
& & CLIL & 22.08 & 26.14 & & \\
\hline
\end{tabular}

When contrasting non-CLIL students from different types of schools (public and charter) we are unable to detect any statistically significant differences, suggesting out-of-school learning habits on the subject of English for non-CLIL students are similar despite being enrolled in schools with different characteristics.

In order to give an insight into the methods students take advantage of in order to learn English in their free time, we can observe that reading books and magazines, surfing the Internet, playing videogames or listening to songs are employed to a greater extent by CLIL students than by the non-CLIL participants, in line with Sundqvist and Sylvén's (2016) affirmation that gaming is taking centre stage in the extramural exposure arena.

\subsection{Language attainment according to learning methodology (CLIL and extra FI)}

\subsubsection{CLIL students that are not exposed to extra FI compared to non-CLIL students that are exposed to extra FI (private academies)}

The CLIL students (who do not have extra formal instruction out of school) outperform their non-CLIL counterparts (who do have access to extra English in academies) in terms of language competence on the whole when we acknowledge both stages of education together. Delving deeper to provide finer-grained detail of the findings, we can observe that the CLIL students (who have traditional EFL lessons alongside content lessons taught through the FL in school) are more proficient in terms of use of English, highlighting a better grasp of grammar than non-CLIL students (who receive additional formal instruction out of school) (cf. Table 6). This is an interesting finding given scholars have voiced concern that a focus on form is often not contemplated in CLIL teaching (Pérez-Vidal, 2010). Paying attention to each stage individually, it is indisputable that the Secondary Education CLIL and non-CLIL students present more of a disparity in their language skills when we scrutinize the results. We are able to identify a more advanced ability on behalf of the CLIL students almost across the board (cf. Table 7). The only skills not to reveal any differences were reading and speaking, although CLIL students were found to demonstrate superior pronunciation skills, deviating from prior research which reports on CLIL students not developing more accurate pronunciation as a result of a CLIL programme (Gallardo del Puerto, Gómez Lacabex \& García 
Lecumberri, 2009; Pérez Cañado \& Lancaster, 2017; Rallo Fabra \& Jacob, 2015) (cf. Table 8). Within Primary Education, no statistically significant differences can be found on any of the tests, suggesting the effects of CLIL programmes are more likely to be effective in the long term. We are led to believe, on the premise of these findings, that a CLIL programme alone develops English skills to a greater degree than FI tallying with outcomes set forth in Pérez-Vidal (2010) and Dewey (2008). Possible reasons for this tendency could be attributed to the fact that the CLIL students are subject to increased meaningful exposure as opposed to an increase in amount of FI. On the contrary, the mere fact that no statistically significant differences are found in favour of the non-CLIL group (who have the advantage of extra formal instruction) casts doubts on the effectiveness of private academies.

Table 6. General language attainment results for CLIL students (no FI) and non-CLIL students (FI)

\begin{tabular}{|ll|r|r|r|r|}
\hline & Group & \multicolumn{1}{c|}{ Mean } & $\begin{array}{r}\text { Standard } \\
\text { deviation }\end{array}$ & Cohen's d & p value \\
\hline Use of English & Non-CLIL & 15.55 & 8.27 & -0.512 & 0.001 \\
& CLIL & 21.04 & 11.84 & & \\
Vocabulary & Non-CLIL & 8.05 & 3.63 & -0.225 & 0.169 \\
& CLIL & 8.90 & 3.84 & & \\
\multirow{4}{*}{ Listening } & Non-CLIL & 7.83 & 4.21 & 0.101 & 0.575 \\
& CLIL & 7.48 & 2.98 & & \\
Reading & Non-CLIL & 4.50 & 3.18 & 0.113 & 0.516 \\
& CLIL & 4.18 & 2.61 & & \\
\multirow{2}{*}{ Total } & Non-CLIL & 35.93 & 13.73 & -0.401 & 0.015 \\
& CLIL & 41.60 & 14.35 & & \\
\hline
\end{tabular}


Table 7. Language attainment results according to educational level for CLIL students (no FI) and non-CLIL students (FI)

\begin{tabular}{|c|c|c|c|c|c|c|}
\hline $\begin{array}{c}\text { Educational } \\
\text { level }\end{array}$ & & Group & Mean & $\begin{array}{l}\text { Standard } \\
\text { deviation }\end{array}$ & Cohen's d & $p$ value \\
\hline \multirow[t]{10}{*}{$\begin{array}{l}\text { Primary } \\
\text { Education }\end{array}$} & $\begin{array}{l}\text { Use of } \\
\text { English }\end{array}$ & Non-CLIL & 12.29 & 6.05 & 0.170 & 0.431 \\
\hline & & CLIL & 11.27 & 5.93 & & \\
\hline & Vocabulary & Non-CLIL & 8.18 & 4.01 & 0.005 & 0.976 \\
\hline & & CLIL & 8.16 & 4.40 & & \\
\hline & Listening & Non-CLIL & 10.11 & 3.27 & -0.039 & 0.870 \\
\hline & & CLIL & 10.20 & 1.05 & & \\
\hline & Reading & Non-CLIL & 5.32 & 3.52 & 0.170 & 0.430 \\
\hline & & CLIL & 4.75 & 3.22 & & \\
\hline & Total & Non-CLIL & 35.89 & 14.62 & 0.113 & 0.598 \\
\hline & & CLIL & 34.37 & 12.44 & & \\
\hline \multirow[t]{10}{*}{$\begin{array}{l}\text { Secondary } \\
\text { Education }\end{array}$} & $\begin{array}{l}\text { Use of } \\
\text { English }\end{array}$ & Non-CLIL & 21.75 & 8.48 & -1.048 & $<0.001$ \\
\hline & & CLIL & 30.26 & 7.98 & & \\
\hline & Vocabulary & Non-CLIL & 7.80 & 2.85 & -0.593 & 0.026 \\
\hline & & CLIL & 9.61 & 3.11 & & \\
\hline & Listening & Non-CLIL & 3.50 & 1.50 & -0.888 & 0.001 \\
\hline & & CLIL & 4.91 & 1.61 & & \\
\hline & Reading & Non-CLIL & 2.95 & 1.50 & -0.419 & 0.115 \\
\hline & & CLIL & 3.65 & 1.72 & & \\
\hline & Total & Non-CLIL & 36.00 & 12.21 & -0.990 & $<0.001$ \\
\hline & & CLIL & 48.43 & 12.67 & & \\
\hline
\end{tabular}


Table 8. Language attainment results for speaking skills according to educational level for CLIL students (no FI) and non-CLIL students (FI)

\begin{tabular}{|c|c|c|c|c|c|c|}
\hline $\begin{array}{c}\text { Educational } \\
\text { level }\end{array}$ & & Group & Mean & $\begin{array}{l}\text { Standard } \\
\text { deviation }\end{array}$ & Cohen's d & $p$ value \\
\hline \multirow[t]{12}{*}{$\begin{array}{l}\text { Primary } \\
\text { Education }\end{array}$} & \multirow[t]{2}{*}{ Speaking Total } & Non-CLIL & 7.50 & 2.82 & \multirow[t]{2}{*}{$-0,087$} & \multirow[t]{2}{*}{0,911} \\
\hline & & CLIL & 7.70 & 2.34 & & \\
\hline & \multirow[t]{2}{*}{ Grammatical } & Non-CLIL & 1.50 & 0.70 & \multirow[t]{2}{*}{0,071} & \multirow[t]{2}{*}{0,928} \\
\hline & & CLIL & 1.45 & 0.58 & & \\
\hline & \multirow[t]{2}{*}{ Lexical/Range } & Non-CLIL & 1.25 & 0.35 & \multirow[t]{2}{*}{-0.367} & \multirow[t]{2}{*}{0.639} \\
\hline & & CLIL & 1.48 & 0.58 & & \\
\hline & \multirow[t]{2}{*}{ Fluency/Interaction } & Non-CLIL & 1.50 & 0.70 & \multirow[t]{2}{*}{-0.185} & \multirow[t]{2}{*}{0.812} \\
\hline & & CLIL & 1.53 & 0.41 & & \\
\hline & \multirow[t]{2}{*}{ Pronunciation } & Non-CLIL & 1.75 & 0.35 & \multirow[t]{2}{*}{0.000} & \multirow[t]{2}{*}{1.000} \\
\hline & & CLIL & 1.75 & 0.39 & & \\
\hline & \multirow[t]{2}{*}{ Task Fulfilment } & Non-CLIL & 1.50 & 0.70 & \multirow[t]{2}{*}{0.081} & \multirow[t]{2}{*}{0.918} \\
\hline & & CLIL & 1.45 & 0.49 & & \\
\hline \multirow[t]{12}{*}{$\begin{array}{l}\text { Secndary } \\
\text { Education }\end{array}$} & \multirow[t]{2}{*}{ Speaking Total } & Non-CLIL & 6.00 & 3.27 & \multirow[t]{2}{*}{-2.274} & \multirow[t]{2}{*}{0.195} \\
\hline & & CLIL & 9.62 & 0.44 & & \\
\hline & \multirow[t]{2}{*}{ Grammatical } & Non-CLIL & 1.16 & 0.76 & \multirow[t]{2}{*}{-1.355} & \multirow[t]{2}{*}{0.316} \\
\hline & & CLIL & 1.75 & 0.26 & & \\
\hline & \multirow[t]{2}{*}{ Lexical/Range } & Non-CLIL & 1.16 & 0.76 & \multirow[t]{2}{*}{-1.965} & \multirow[t]{2}{*}{0.221} \\
\hline & & CLIL & 1.93 & 0.17 & & \\
\hline & \multirow[t]{2}{*}{ Fluency/Interaction } & Non-CLIL & 1.16 & 0.76 & \multirow[t]{2}{*}{-2.314} & \multirow[t]{2}{*}{0.199} \\
\hline & & CLIL & 2.00 & 0.00 & & \\
\hline & \multirow[t]{2}{*}{ Pronunciation } & Non-CLIL & 1.50 & 0.50 & -1.550 & 0.048 \\
\hline & & CLIL & 1.93 & 0.17 & & \\
\hline & Task Fulfilment & Non-CLIL & 1.00 & 0.50 & -4.243 & 0.074 \\
\hline & & CLIL & 2.00 & 0.00 & & \\
\hline
\end{tabular}

4.2.2. CLIL students that are exposed to extra FI compared to non-CLIL students that are exposed to extra FI (private academies)

Turning to a comparison of the CLIL and non-CLIL groups, both of whom attend private academies after school (furnishing extra formal instruction for both groups), we find it is the CLIL students in the $4^{\text {th }}$ grade that surpass their non-CLIL peers. We are able to detect statistically significant differences in favour of the CLIL group when all tests are considered concurrently and for the individual skills of use of English and listening (cf. Table 9). This outcome for listening competence tallies with previous studies which have examined the effects of CLIL on the oral receptive skills of learners in comparison to those learners who have studied in an EFL environment (Lasagabaster, 2008; Pérez Cañado \& Lancaster, 2017; Stotz and Meuter, 2003). When evaluating outcomes for the two educational stages as one entity, no differences emerge for general language ability or for any specific skill, a 
situation mirrored for Primary Education alone. This outcome could be deemed surprising due to the fact the non-CLIL cohort includes students who attend charter schools which are commonly looked upon with high regard and many parents enrol their children in these types of schools in order for their children to excel to a greater extent than they would in a public school; however it is evident that the students that do, in fact, take precedence are from the CLIL cohort within the public bilingual school. It is noteworthy to point out that if we compare the situation analysed in this section (4.2.2) to the previous section (4.2.1), it is clear that proficiency flourishes further for the CLIL students if they are not receiving extra FI, as we can detect a higher number of statistically significant differences between the experimental and control groups in favour of the former when both Primary and Secondary are considered together and, in addition, when referring to $4^{\text {th }}$ grade alone we discover that CLIL positively affects a wider range of skills. In this sense, it is indicated that extra FI should not only be called into question in terms of efficacy, but voices a concern as regards the possible detrimental effect it could have on language proficiency.

Table 9. Language attainment results according to educational level for CLIL students (FI) and non-CLIL students (FI)

\begin{tabular}{|c|c|c|c|c|c|c|}
\hline $\begin{array}{c}\text { Educational } \\
\text { level }\end{array}$ & & Group & Mean & $\begin{array}{l}\text { Standard } \\
\text { deviation }\end{array}$ & Cohen's d & $p$ value \\
\hline \multirow[t]{10}{*}{$\begin{array}{l}\text { Primary } \\
\text { Education }\end{array}$} & \multirow[t]{2}{*}{ Use of English } & Non-CLIL & 12.29 & 6.05 & \multirow[t]{2}{*}{0127} & \multirow[t]{2}{*}{0.602} \\
\hline & & CLIL & 11.48 & 6.70 & & \\
\hline & \multirow[t]{2}{*}{ Vocabulary } & Non-CLIL & 8.18 & 4.01 & \multirow[t]{2}{*}{-0.101} & \multirow[t]{2}{*}{0.682} \\
\hline & & CLIL & 8.58 & 3.93 & & \\
\hline & \multirow[t]{2}{*}{ Listening } & Non-CLIL & 10.11 & 3.27 & \multirow[t]{2}{*}{0.085} & \multirow[t]{2}{*}{0.733} \\
\hline & & CLIL & 9.87 & 2.17 & & \\
\hline & \multirow[t]{2}{*}{ Reading } & Non-CLIL & 5.32 & 3.52 & \multirow[t]{2}{*}{0.100} & \multirow[t]{2}{*}{0.686} \\
\hline & & CLIL & 5.00 & 2.78 & & \\
\hline & \multirow[t]{2}{*}{ Total } & Non-CLIL & 35.89 & 14.62 & \multirow[t]{2}{*}{0.069} & \multirow[t]{2}{*}{0.775} \\
\hline & & CLIL & 34.94 & 12.65 & & \\
\hline \multirow[t]{10}{*}{$\begin{array}{l}\text { Secondary } \\
\text { Education }\end{array}$} & \multirow[t]{2}{*}{ Use of English } & Non-CLIL & 21.75 & 8.48 & \multirow[t]{2}{*}{-0.937} & \multirow[t]{2}{*}{0.005} \\
\hline & & CLIL & 30.75 & 10.60 & & \\
\hline & \multirow[t]{2}{*}{ Vocabulary } & Non-CLIL & 7.80 & 2.85 & \multirow[t]{2}{*}{-0.472} & \multirow[t]{2}{*}{0.144} \\
\hline & & CLIL & 9.50 & 4.21 & & \\
\hline & \multirow[t]{2}{*}{ Listening } & Non-CLIL & 3.50 & 1.50 & \multirow[t]{2}{*}{-0.937} & \multirow[t]{2}{*}{0.005} \\
\hline & & CLIL & 5.05 & 1.79 & & \\
\hline & \multirow[t]{2}{*}{ Reading } & Non-CLIL & 2.95 & 1.50 & \multirow[t]{2}{*}{-0.388} & \multirow[t]{2}{*}{0.228} \\
\hline & & CLIL & 3.65 & 2.05 & & \\
\hline & \multirow[t]{2}{*}{ Total } & Non-CLIL & 36.00 & 12.21 & \multirow[t]{2}{*}{-0.883} & \multirow[t]{2}{*}{0.008} \\
\hline & & CLIL & 48.95 & 16.75 & & \\
\hline
\end{tabular}




\subsection{Interpretation of the language attainment differential between the CLIL and the non-CLIL groups}

With a view to clarifying the differences between the CLIL and non-CLIL group pertaining to L2 proficiency, consecutive discriminant analyses have been carried out. This has allowed us to examine the discriminating potential of each individual independent and moderating variable incorporated into this study of CLIL and non-CLIL students. It must be highlighted that the selection of variables has been established taking into account those that appear to hold greater implications in the event of assessing the equality of group means.

It transpires that the language attainment differential can be primarily ascribed to the independent variable (the CLIL programme itself) in both Primary and Secondary Education. In the former educational stage, it has the greatest weight in explaining the differences between the bilingual and non-bilingual groups, together with SES (cf. Tables 10, 11 and 12). In turn, at the end of Compulsory Secondary Education, the significance of SES diminishes, while that of the CLIL programme is maintained and, interestingly, extramural exposure acquires a sharper relief in explaining the differences between the CLIL and non-CLIL groups, together with the motivational aspect of lack of interest (cf. Tables 13, 14 and 15). Thus, the greater extramural exposure which was documented for the CLIL groups at the end of this second educational stage appears to be exerting a positive influence on the language level of the bilingual group, together with the CLIL programme in itself, as both variables have the greatest discriminating potential. It would therefore be desirable to favour exposure to the foreign language through CLIL in school and further extramural exposure to it beyond the confines of the classroom in order to boost the language attainment of students in monolingual contexts.

Table 10. Test of equality of group means for Primary Education

\begin{tabular}{|l|c|c|r|r|l|}
\hline & $\begin{array}{c}\text { Wilks' } \\
\text { Lamda }\end{array}$ & F & gl1 & gl2 & Sig. \\
\hline Setting & 0.910 & 1.983 & 1 & 20 & 0.174 \\
Socioeconomic Status & 0.751 & 6.633 & 1 & 20 & 0.018 \\
Verbal intelligence & 0.958 & 0.869 & 1 & 20 & 0.362 \\
Willingness & 0.984 & 0.329 & 1 & 20 & 0.573 \\
Anxiety & 0.994 & 0.116 & 1 & 20 & 0.737 \\
Lack of interest & 0.994 & 0.125 & 1 & 20 & 0.728 \\
Self-commitment & 0.876 & 2.828 & 1 & 20 & 0.108 \\
L1 & 0.958 & 0.877 & 1 & 20 & 0.360 \\
Content subject grade & 0.983 & 0.353 & 1 & 20 & 0.559 \\
Extramural exposure & 0.996 & 0.082 & 1 & 20 & 0.777
\end{tabular}


Table 10. Test of equality of group means for Primary Education. (Continuation)

\begin{tabular}{|l|r|r|r|r|r|} 
Use English & 0.984 & 0.333 & 1 & 20 & 0.570 \\
Listening & 0.780 & 5.637 & 1 & 20 & 0.028 \\
Reading & 0.879 & 2.750 & 1 & 20 & 0.113 \\
Total & 0.918 & 1.783 & 1 & 20 & 0.197 \\
Speaking_Total & 0.903 & 2.153 & 1 & 0 & 0.158 \\
Grammatical & 0.788 & 5.386 & 1 & 20 & 0.031 \\
Lexical range & 0.838 & 3.857 & 1 & 20 & 0.064 \\
Fluency/Interaction & 0.774 & 5.855 & 1 & 20 & 0.025 \\
Pronunciation & 0.743 & 6.910 & 1 & 20 & 0.016 \\
Task fulfilment & 0.808 & 4.761 & 1 & 20 & 0.041 \\
\hline
\end{tabular}

Tables 11 and 12. Summary of canonical discriminant functions for Primary Education

\begin{tabular}{|c|r|r|r|r|}
\hline Function & Eigenvalue & \% variance & Cumulative \% & $\begin{array}{c}\text { Canonical } \\
\text { correlation }\end{array}$ \\
\hline 1 & 8.096 & 100.0 & 100.0 & 0.943 \\
\hline
\end{tabular}

\begin{tabular}{|l|r|r|r|r|}
\hline Test of function & Wilks' Lamda & Chi-square & gl & Sig. \\
\hline 1 & .110 & 25.390 & 17 & 0.086 \\
\hline
\end{tabular}

Table 13. Test of equality of group means for Secondary Education

\begin{tabular}{|l|r|r|r|r|l|}
\hline & $\begin{array}{c}\text { Wilks' } \\
\text { Lamda }\end{array}$ & F & gl1 & gl2 & Sig. \\
\hline Setting & 0.992 & 0.184 & 1 & 23 & 0.672 \\
Socioeconomic Status & 0.883 & 3.051 & 1 & 23 & 0.094 \\
Verbal intelligence & 0.987 & 0.300 & 1 & 23 & 0.589 \\
Willingness & 0.912 & 2.233 & 1 & 23 & 0.149 \\
Anxiety & 0.947 & 1.299 & 1 & 23 & 0.266 \\
Lack of interest & 0.736 & 8.254 & 1 & 23 & 0.009 \\
\hline
\end{tabular}


Table 13. Test of equality of group means for Secondary Education. (Continuation)

\begin{tabular}{|l|c|c|c|c|c|}
\hline & $\begin{array}{c}\text { Wilks' } \\
\text { Lamda }\end{array}$ & F & gl1 & gl2 & Sig. \\
\hline Self-commitment & 0.946 & 1.326 & 1 & 23 & 0.261 \\
L1 & 0.999 & 0.028 & 1 & 23 & 0.870 \\
Content subject grade & 0.967 & 0.796 & 1 & 23 & 0.382 \\
Extramural exposure & 0.767 & 6.974 & 1 & 23 & 0.015 \\
Use English & 0.894 & 2.739 & 1 & 23 & 0.111 \\
Vocabulary & 0.947 & 1.285 & 1 & 23 & 0.269 \\
Listening & 0.761 & 7.216 & 1 & 23 & 0.013 \\
Reading & 0.959 & 0.988 & 1 & 23 & 0.331 \\
Total & 0.873 & 3.352 & 1 & 23 & 0.080 \\
Speaking_Total & 0.648 & 12.472 & 1 & 23 & 0.002 \\
Grammatical & 0.825 & 4.879 & 1 & 23 & 0.037 \\
Lexical range & 0.736 & 8.263 & 1 & 23 & 0.009 \\
Fluency/Interaction & 0.648 & 12.479 & 1 & 23 & 0.002 \\
Pronunciation & 0.653 & 12.203 & 1 & 23 & 0.002 \\
Task fulfilment & 0.481 & 24.840 & 1 & 23 & $<0.001$ \\
\hline
\end{tabular}

Tables 14 and 15. Summary of canonical discriminant functions for Secondary Education

\begin{tabular}{|l|c|c|c|c|}
\hline Function & Eigen value & \% variance & Cumulative \% & \multicolumn{2}{|c|}{$\begin{array}{c}\text { Canonical } \\
\text { correlations }\end{array}$} \\
\hline 1 & 9.354 & 100.0 & 100.0 & 0.950 \\
\hline
\end{tabular}

\begin{tabular}{|l|r|r|r|rr|}
\hline Test of function & $\begin{array}{c}\text { Wilks' } \\
\text { Lamda }\end{array}$ & Chi-square & gl & \multicolumn{2}{|c|}{ Sig. } \\
\hline 1 & 0.097 & 31.554 & 19 & 0.035 \\
\hline
\end{tabular}

\section{Conclusion}

By virtue of this current investigation, we have been able to provide findings on the topic of extramural exposure and language attainment by examining input-related variables in CLIL programmes. Both Primary and Secondary students in two different types of schools have been analysed in the monolingual autonomous community of Extremadura. We have paid attention to superseding the principal limitations of previous studies in terms of guaranteeing homogeneity, factoring in intervening variables and conducting multivariate analyses. 
Relating to RQ1, we have ascertained that CLIL scenarios favour more extramural exposure to English when Primary and Secondary Education are analysed together. When the two different educational stages are scrutinized separately, we can perceive that it is the CLIL Secondary students in $4^{\text {th }}$ grade that dedicate more hours to learning English outside of school in comparison to non-CLIL students. In the case of Primary Education alone, no statistically significant differences are detected. A similar pattern ensues for CLIL and nonCLIL students when we focus on public schools, as it is the $4^{\text {th }}$ grade Secondary students that appear to engage in extramural English, whereas the CLIL students in a public school, across the range of educational levels, demonstrate tendencies towards spending more time learning English out of school hours than the non-CLIL students from charter schools. On inspection of both groups of non-CLIL students (those belonging to the non-CLIL stream in public schools and the charter school students) we are unable to underpin any differences in their extramural English habits. Exploring the types of extramural English students are participating in, we find that CLIL students concentrate on reading, the Internet, videogames and listening to English music to a greater degree than the non-CLIL students. In light of the fact that CLIL students unveiled a higher predisposition to engage in extramural English, it is desirable to continue promoting extramural activities in all learning settings. Previous research claims that extramural exposure aids L2 learning, expressly digital sources, and it is paramount for teachers to acknowledge the importance of extramural activities, to get to grips with the types which would benefit their students and master how to incorporate material into the classroom.

Turning to address RQ2, we have been able to highlight revelations concerning the effects of CLIL and extra FI on language proficiency. Statistically significant differences between CLIL students with no extra FI and non-CLIL students receiving extra FI for both stages of education have been located enabling us to confirm the superior English language competence of the former, especially in the use of English. Secondary CLIL students outperform non-CLIL peers on use of English, listening, vocabulary and pronunciation skills, indicating CLIL programmes to have more effect in the long term. When both groups are exposed to extra FI, Secondary Education comes forth with statistically significant differences for the CLIL group, specifically on use of English and listening competence, implying that it is these skills that are enhanced by the CLIL programme. Given that the charter school was only represented by non-CLIL students proves that the students with the privilege of a semi-private school environment are not in a favoured position over CLIL students attending a public school when measuring language proficiency. Interestingly, if we take extra FI out of the equation for CLIL students but not the non-CLIL counterparts, we are faced with a CLIL group that not only outperforms their non-CLIL peers but also demonstrates superior language performance on a higher number of skills on the whole and at Secondary level. Only reading and speaking reveal no statistically significant differences, with the exception of pronunciation, which CLIL students prove to dominate better. Taking into consideration CLIL students come out on top in both circumstances provokes food for thought on the topic of the FI provided by private academies. It could be suggested that more parents should encourage their children to take part in CLIL programmes rather than pay for them to attend private academies, especially taking into account that the research implies CLIL students perform better without this extra FI.

Finally, in response to the third and final RQ, the successive discriminant analyses carried out have revealed that the differences between the CLIL and non-CLIL groups as regards language attainment can be primarily ascribed to the independent variable (CLIL) 
and SES in Primary Education and to CLIL and the moderating variable of extramural exposure at the end of CSE. Thus, the meaningful, unconscious, and communicative exposure to the language favoured by CLIL programmes and by extramural activities such as those sampled in this study has very positive effects on the language attainment of students in monolingual contexts most relevant to grammar, vocabulary, listening and pronunciation proficiency. Taking stock of the findings from this research question, it is evident that the taking part in both CLIL programmes and extramural activities should be promoted to a higher degree. Schools need to be aware of the positive pedagogical implications involved and encourage their implementation in educational environments.

In order to acknowledge the possible limitations of the study, it is necessary to underscore that the sample is geographically reduced. It would thus be interesting to increase the sample to examine students from other areas and outside of Spain. The study could be improved considerably if it had a more longitudinal focus, students could be tested over a longer course of time to expose the evolution of results. It would also be worthwhile to delve into other areas of extramural exposure such as SA and immersion to gain insight into their effects on school students.

A study addressing flaws of preceding studies to guarantee homogeneity of groups and considering intervening variables has demonstrated that CLIL students perform better than those students who enrol in extra FI, validating CLIL as a methodology that must be endorsed and developed further without apprehension. All issues pertinent to CLIL need to be adequately supervised, namely coordination and teacher training, to ensure the journey to fully bilingual schools in monolingual communities is a success. In order for CLIL to keep on track, continuous research with solid research designs should be encouraged to delve deeper into the CLIL adventure. We can recommend the way to accomplish this is through the inclusion of intervening variables in research inquiry creating clearer captions of CLIL practice. On this basis, we hope the current study can assist in the development of future studies to drive CLIL to its maximum potential.

\section{REFERENCES}

Arnold, N. (2009). "Online extensive reading for advanced foreign language learners: An evaluation study", in Foreign Language Annals, 42, 2: 340-66.

Barton, D. and Potts. D. (2013). "Language learning online as a social practice", in TESOL Quarterly, 47, 4: 815-20.

Berns, M, Bot, K. and Hasebrink, U. (eds.) (2007). In the presence of English: Media and European youth. New York: Springer.

Bialystok, E. (1981). "The role of conscious strategies in second language proficiency", in The Modern Language Journal, 65, 1: 24-35.

Bruton, A. (2011). "Are the differences between CLIL and non-CLIL groups in Andalusia due to CLIL? A reply to Lorenzo, Casal and Moore (2010)", in Applied Linguistics, 2011: 1-7.

Caimi, A. (2006). "Audiovisual translation and language learning: the promotion of intralingual subtitles", in The Journal of Specialised Translation, 6: 85-89.

Chik, A. and Breidbach, S. (2011). "Online language learning histories exchange: Honk Kong and German Perspectives", in TESOL Quarterly, 45, 3: 553-64.

Dewey, D. P. (2008). Japanese vocabulary acquisition by learners in three contexts", in Frontiers: The Interdisciplinary Journal of Study Abroad, 127-148. 
Dufon, M. A., and Churchill, E. (eds.) (2006). Language learners in study abroad contexts. Clevedon: Multilingual Matters.

d'Ydewalle, G. and Poel, M. (1999). "Incidental foreign-language acquisition by children watching subtitled television programs", in Journal of Psycholinguistic Research, 28, 3: 227-44.

Freed, B. (1995). "Introduction", in B. Freed (ed.), Second language acquisition in a study abroad context. Amsterdam/Philadelphia: John Benjamins, 1-2.

Freed, B., Segalowitz, N. and Dewey. D.P. (2004). "Context of learning and second language fluency in French: Comparing regular classroom, study abroad, and intensive domestic immersion programs", in Studies in Second Language Acquisition, 26, 2: 275-301.

Gallardo del Puerto, F., Gómez Lacabex, E. and García Lecumberri, M. L. (2009). "Testing the effectiveness of content and language integrated learning in foreign language contexts: The assessment of English pronunciation", in Y. Ruiz de Zarobe and R. M. Jiménez Catalan (eds.), Content and language integrated learning: Evidence from research in Europe. Bristol: Multilingual Matters, 63-80.

Gee, J. P. (2007). What videogames have to teach us about learning and literacy. (Revised and updated ed.). New York: Palgrave Macmillan.

Lamb, M. (2004). "'It depends on the students themselves': Independent language learning at an Indonesian state school", in Language, Culture and Curriculum, 17, 3: 229-45.

Lasagabaster, D. (2008). "Foreign language competence in content and language integrated courses", in The Open Applied Linguistics Journal, 1, 31-42.

Lorenzo, F., Casal. S. and Moore, P. (2009). "The effects of language and content integrated learning in European education: Key findings from the Andalusian bilingual sections evaluation project", in Applied Linguistics, 31, 3: 418-442.

Madrid, D., Bueno, A. and Ráez, J. (In press). "Investigating the effects of CLIL on language attainment: Instrument design and validation". in M. L. Pérez Cañado (ed.), Content and Language lntegrated Learning in monolingual settings: New lnsights from the Spanish context. Amsterdam: Springer.

Meyer, O., Coyle. D., Halbach, A., Schuck, K. and Ting, T. (2015). "A pluriliteracies approach to content and language integrated learning-mapping learner progressions in knowledge construction and meaning making", in Language, Culture and Curriculum, 28, 1: 41-57.

Olssen, E. and Sylvén, L.K. (2015). "Extramural English and academic vocabulary. A longitudinal study of CLIL and non-CLIL students in Sweden", in Apples-Journal of Applied Language Studies, 9, 2: 77-103.

Paran, A. (2103). "Content and language integrated learning: Panacea or policy borrowing myth?", in Applied Linguistics Review, 4, 2: 317-342.

Pearson, N. (2004). "The idiosyncrasies of out-of-class language learning: A study of mainland Chinese students studying English at tertiary level in New Zealand", in Supporting independent learning in the $21^{\text {st }}$ century. Proceedings of the inaugural conference of the Independent Learning Association, 13-14 September 2003, Auckland. Available from: http://independentlearning.org/ILA/ila03/ila03_pearson.pdf.

Pelechano, V. (1994). "Prueba MA", in Análisis y Modificación de la Conducta, 20: 71-72.

Pérez Cañado, M. L. (2011). "The effects of CLIL within the APPP: Lessons learned and ways forward", in R. Crespo and M. García de Sola (eds.), Studies in Honour of Ángeles Linde López. Granada: Universidad de Granada, 389-406.

Pérez Cañado, M. L., and Lancaster, N. K. (2017). "The effects of CLIL on oral comprehension and production: a longitudinal case study", in Language, Culture and Curriculum, 30, 3: 300-316.

Pérez-Vidal, C. (2010). "Language acquisition in three different contexts of learning: Formal instruction, stay abroad and semi-immersion (CLIL)", in Y. Ruiz de Zarobe, J. M. Sierra, 
and E. Gallardo del Puerto (eds.), Content and foreign language integrated Learning: Contributions to multilingualism in European contexts. Bern/Berlin: Peter Lang, 23-35.

Purushotma, R. (2005). "You're not studying, you're just...", in Language Learning and Technology, 9, 1: 80-96.

Rallo Fabra, L. and Jacob, K. (2015). "Does CLIL enhance oral skills? Fluency and pronunciation errors by Spanish-Catalan learners of English", in M. Juan-Garau and J. Salazar Noguera (eds.), Content-based language learning in multilingual educational environments, 163177. DOI: $10.1007 / 978-3-319-11496-5$.

Rogers, M. and Webb, S. (2011). "Narrow viewing: The vocabulary in related television programs", in TESOL Quarterly, 45, 4: 689-717.

Saaski, M. (2004). "A multiple-data analysis of the 3-5 year development of EFL student writers", in Language Learning, 54, 3: 525-82.

Santamaría, P., Arribas, D., Pereña, J. and Seisdedos, N. (2016). EFAI. Evaluación factorial de las aptitudes intelectuales. Madrid: TEA Ediciones.

Segolowitz, N. and Freed, B. (2004). "Context, contact, and cognition in oral fluency acquisition: Learning Spanish in at-home and study abroad contexts", in Studies in Second Language Acquisition, 26, 2: 173-99.

Stotz, D. and Meuter, T. (2003). "Embedded English: Integrating content and language learning in a Swiss primary school project", in Le Bulletin Suisses de Linguistique Appliquée, 77, 83-101.

Sundqvist, P. (2009). Extramural English matters: Out-of-school English and its impact on Swedish ninth graders' oral proficiency and vocabulary. (Diss.), Karlstad University: Karlstad.

Sundqvist, P. and Sylvén, L. K. (2014). "Language-related computer use: Focus on young L2 English learners in Sweden", in ReCALL, 26, 1: 3-20.

Sundqvist, P. and Sylvén, L. K. (2016). Extramural English in teaching and learning: From theory and research to practice. London: Palgrave Macmillan.

Sylvén, L. K. (2004b/2010). Teaching in English or English teaching? On the effects of content and learning integrated learning on Swedish learners' incidental vocabulary acquisition. (Diss.), Acta Universitatis Gothoburgensis: Gothenburg.

Sylvén, L. K. (2006). "How is extramural exposure to English among Swedish school students used in the CLIL classroom?", in C. Dalton-Puffer and T. Nikula (eds.), Vienna English working papers, 15, 3: 47-53.

Sylvén, L. K. and Sundqvist, P. (2012). "Similarities between playing World of Warcraft and CLIL", in Apples-Journal of Applied Language Studies, 6, 2: 113-30.

Sylvén, L. K., and Sundqvist, P. (2015). "Extramural English in relation to CLIL: Focus on young language learners in Sweden", in S. Marsh, M. L. Pérez Cañado and J. Ráez Padilla (eds.), CLIL in Action: Voices from the classroom. Newcastle-upon-Tyne: Cambridge Scholars Publishing, 47-62.

Talaván Zanón, N. (2013). La subtitulación en el aprendizaje de lenguas extranjeras. Barcelona: Octaedro.

\section{ACKNOWLedgements}

This work was supported by the Spanish Ministry of Economy and Competitiveness, under Grant FFI2012-32221, and by the Junta de Andalucía, under Grant P12-HUM-23480. We would also like to thank the school management and the students who participated in the study. 